(Halaman ini sengaja dikosongkan) 


\title{
MAKAM-MAKAM DAN CANDI DI NEGERI BARU DALAM PERKEMBANGAN SEJARAH BUDAYA DI KABUPATEN KETAPANG
}

\author{
Bambang Sakti Wiku Atmojo
}

Balai Arkeologi Banjarmasin, Jalan Gotong Royong II, RT 03/06, Banjarbaru 70711, Kalimantan Selatan; Telepon (0511) 4781716; Facsimile (0511) 4781716; email: bambang.wiku@yahoo.com

\begin{abstract}
Abstrak. Salah satu manfaat peninggalan budaya masa lalu adalah untuk merekonstruksi perkembangan sejarah budaya. Peninggalan budaya baik fisik maupun non fisik banyak ditemukan di berbagai daerah, salah satunya di Desa Negeri Baru, Kabupaten Ketapang, Kalimantan Barat. Desa tersebut memiliki banyak peninggalan kepurbakalaan yang merupakan warisan budaya masa lalu, baik berupa artefak, situs, bangunan, dan struktur. Peninggalan kepurbakalaan tersebut ada yang berlatar belakang budaya Hindu dan ada yang berlatar belakang budaya Islam. Adanya berbagai jenis peninggalan dengan berbagai ragam latar belakang budaya tersebut mengindikasikan bahwa dahulu desa tersebut merupakan sebuah kawasan hunian yang cukup besar pada masanya. Adanya bangunan makam yang tidak jauh lokasinya dengan candi dapat diasumsikan sebagai sebuah kerukunan antarpemeluk agama yang berbeda, yang telah terjalin sejak lama. Hal tersebut juga menunjukkan bahwa keragaman budaya merupakan bagian dari kehidupan masyarakat sejak zaman dahulu.
\end{abstract}

Kata Kunci: makam, budaya kuno, budaya baru, keselarasan agama, Negeri Baru, Ketapang

\begin{abstract}
ANCIENT TOMBS AND TEMPLE IN NEGERI BARU DURING THE HISTORIC CULTURAL DEVELOPMENT IN THE DISTRICT OF KETAPANG. One of of cultural heritage benefits is to reconstruct the history of cultural development. The cultural heritage both tangible and intangible have been found in the many regions, such as Negeri Baru Village in Ketapang District, West Kalimantan Province. This village has many cultural heritage, artifacts, sites, buildings, and structures. Those heritage have Hinduism and Islamic backgrounds which are indicating that the village was a large ancient settlement. The location of Islamic ancient tombs near the Hindu temple can be assumed as the the harmony among adherents who had different religions since the past. It also suggests that cultural diversity was being a part of the local society since the immemorial time.
\end{abstract}

Keywords : tomb, Islam, ancient culture, new culture, religious harmony, Negeri Baru, Ketapang

\section{A. Pendahuluan}

Minimnya peninggalan yang berlatar belakang agama Hindu-Buddha dan awal masuknya agama Islam di Kalimantan Barat memunculkan berbagai persepsi. Bisa jadi, potensi kedua peninggalan tersebut sedikit, mungkin juga karena kurangnya aktivitas penelitian yang mengarah kepada kedua jenis peninggalan tersebut. Setelah melalui berbagai penelitian awal yang sifatnya eksplorasi, dapat diyakini bahwa sebetulnya terdapat sejumlah peninggalan arkeologi yang memiliki keterkaitan dengan kedua masa tersebut. Penelusuran terhadap peninggalan dari kedua masa tersebut penting, terutama untuk dapat merangkai perkembangan sejarah budaya yang terjadi di Kalimantan Barat. Selama ini terdapat kesulitan karena data peninggalan arkeologis di Kalimantan Barat rata-rata berasal dari masa abad ke-18 dan seterusnya, sedangkan dari masa yang lebih tua sangat jarang. Salah satu daerah yang memiliki potensi untuk peninggalan-peninggalan dari masa yang lebih tua adalah Kabupaten Ketapang.

Kabupaten Ketapang merupakan bagian dari Propinsi Kalimantan Barat, yang terletak di bagian selatan, dan memiliki wilayah pantai yang memanjang dari utara ke selatan, dataran rendah, dataran rawa, 
sampai perbukitan. Wilayah daerah aliran sungai merupakan dataran berawa-rawa, sedangkan wilayah hulu sungai umumnya berupa daerah berbukit-bukit. Sungai terpanjang di Kabupaten Ketapang adalah Sungai Pawan, sebuah sungai besar yang mengalir mulai dari pedalaman, menyusuri dataran tinggi dan rendah, dan bermuara di Selat Karimata. Sungai tersebut menghubungkan Kota Ketapang dengan beberapa kecamatan di pedalaman, antara lain Sendai dan Nanga Tayap. Selain itu, juga terdapat sungaisungai besar lainnya, yakni Sungai Merawan, Kendawangan, dan Jelai.

Adapun batas-batas wilayah administrasi Kabupaten Ketapang adalah di sebelah utara berbatasan dengan Kabupaten Pontianak dan Sanggau, di sebelah timur berbatasan dengan Kabupaten Sintang dan Propinsi Kalimantan Tengah, di sebelah selatan adalah Laut Jawa, sedangkan di sebelah barat berbatasan dengan Selat Karimata dan Kabupaten Kayong Utara

Sebagaimana daerah-daerah lain, Kabupaten Ketapang juga memiliki sejarah penghunian masa lampau yang cukup panjang. Namun demikian, tidak semua masa lalu dapat diungkapkan kembali karena penelitian ke arah tersebut belum banyak dilaksanakan. Sisa-sisa pemukiman kehidupan yang dapat memberi petunjuk pemanfaatan kawasan pada masa lalu adalah sebaran fragmen keramik. Sebaran keramik ini banyak ditemukan di daerah Negeri Baru, sampai ke daerah Mulia Kerta. Selain sebaran keramik, di Negeri Baru juga terdapat reruntuhan bekas bangunan dari bata yang mengindikasikan sebagai bekas candi, parit kuna, dan beberapa kompleks makam. Sebaran keramik banyak diketemukan di luar reruntuhan bangunan candi tersebut, sedangkan di dalam reruntuhan itu sendiri temuan keramik minim sekali. Dalam hal ini mungkin dapat diasumsikan bahwa reruntuhan bangunan candi di Negeri Baru tersebut bukan suatu bangunan hunian atau bukan suatu bangunan yang ditempati sehari-hari. Bangunan hunian justru terletak di sekitar reruntuhan bangunan hingga ke tepi Sungai Pawan, yang menunjukkan bahwa daerah Negeri Baru ini pada masa lalu bukanlah desa biasa. Adanya pecahan-pecahan keramik yang dapat ditemukan dalam area cukup luas, baik di seputar Candi Negeri Baru maupun tepian Sungai Pawan pada jarak sekitar 750 meter dari candi merupakan suatu indikasi adanya pemukiman yang cukup padat di desa tersebut pada masa lalu.

Adanya berbagai jenis peninggalan kuna tersebut menimbulkan suatu asumsi bahwa pada masa lalu desa tersebut merupakan desa besar dan memiliki peranan cukup penting untuk wilayah Ketapang. Bisa jadi dahulu terdapat sebuah pemukiman besar, yang memiliki rentang penghunian cukup lama, yang dibuktikan dengan adanya peninggalan kepurbakalaan masa Hindu-Buddha sampai masa Islam. Namun demikian dugaan ini masih perlu pembuktian lebih lanjut, mengingat masih banyak data kekunaan yang belum terungkap. Berdasarkan cerita lisan yang beredar di masyarakat, dahulu daerah tersebut dinamakan kampung lama, yang mengindikasikan sebagai kawasan hunian kuna.Tulisan ini mengetengahkan berbagai jenis kekunaan yang ada di Desa Negeri Baru, hubungan atau keterkaitan antara satu kekunaan dengan kekunaan yang lain, serta posisinya dalam perkembangan budaya setempat. Pembahasan akan dititikberatkan pada peninggalan fisik yang berupa candi dan makam.

\section{B. Tinggalan Kepurbakalaan di Negeri Baru}

Desa Negeri Baru secara administratif merupakan bagian dari Kecamatan Benua Kayong, Kabupaten Ketapang. Desa tersebut dapat dicapai dari Kota Ketapang ke arah timur dengan menggunakan kendaraan darat (mobil atau sepeda motor) selama kurang lebih 30 menit. Selain dengan angkutan darat dapat juga dicapai dengan menggunakan angkutan air menyusuri Sungai Pawan. Desa tersebut terletak di tepi aliran Sungai Pawan yang mengalir dari kawasan pegunungan di pedalaman ke arah Selat Karimata. Desa tersebut relatif merupakan kawasan yang datar, dengan ketinggian antara 0 s.d. 4 meter dari permukaan Sungai Pawan. Pada musim hujan daerah sekitar Sungai Pawan mengalami banjir, sehingga mengakibatkan lahan dataran banjir yang berasal dari bentukan asal fluvial. Beberapa tempat di antaranya merupakan daerah rawa yang diperkirakan merupakan bekas kawasan banjir yang tidak dapat kering. Vegetasi tanaman budi daya yang ditanam masyarakat antara lain padi, kelapa, jeruk, singkong, pisang, jambu, petai cina, dan randu.

Tinggalan bangunan yang dapat dikatakan paling tua di desa tersebut adalah candi bata. Candi bata tersebut saat ini hanya tersisa bagian kaki saja, berjumlah tiga struktur. Denah bangunan pada struktur pertama pertama berukuran 5,3 X 5,4 meter, memiliki empat sudut penampil di bagian depan. Bangunan ini diperkirakan menghadap ke barat. Pada bagian tengah diagonal bangunan ditemukan sumuran dengan ukuran $60 \mathrm{~cm} \times 60 \mathrm{~cm}$ dan kedalaman $160 \mathrm{~cm}$. Sumuran ini pada sebuah candi biasanya merupakan tempat untuk meletakkan peripih, yang biasanya dipasang sebelum menempatkan arca atau lingga yoni di pusat bilik. Berdasarkan reruntuhan yang ada diperkirakan bagian badan lebih kecil daripada bagian kaki, memiliki penampil, relief yang dipahatkan pada bidang berbingkai, serta memiliki antefik pada 


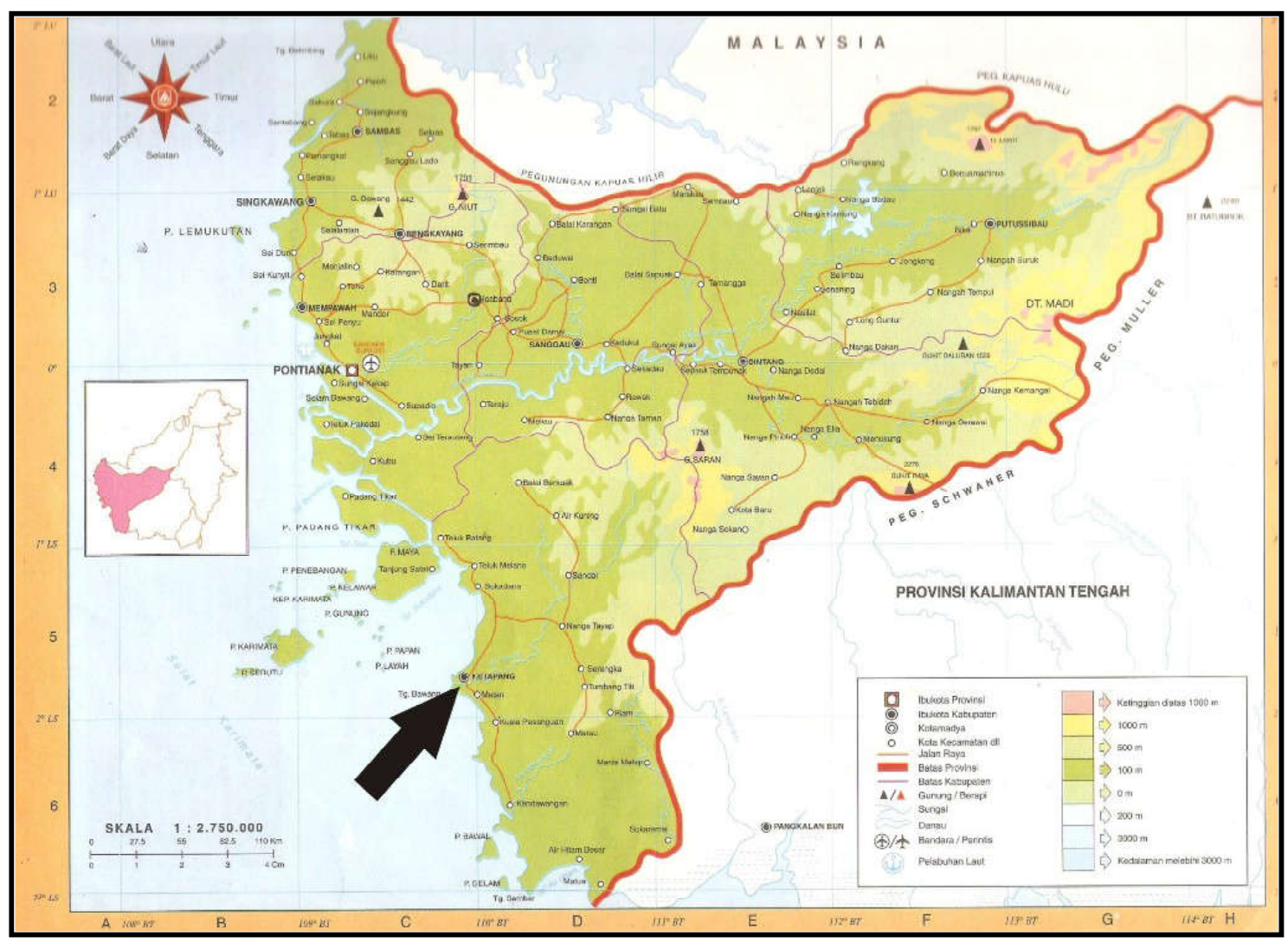

Peta 1. Posisi Ketapang pada peta Kalimantan Barat.

beberapa titik di selasar atas. Relief yang masih dapat dikenali berupa flora terdiri dari daun panjang, bunga jenis ceplok, suluran gelung dan sedikit garis geometris. Candi tersebut didukung dengan fondasi batu putih satu lapis di dalam tanah berpasir.

Bangunan pada struktur kedua dan ketiga hanya tersisa bagian paling bawah, terletak di sebelah selatan struktur pertama. Ukurannya lebih kecil daripada struktur pertama, yaitu 4,6 m x 4,7 m. Jarak antara struktur pertama dengan struktur kedua dan antara struktur kedua dengan ketiga masing-masing lima meter. Oleh karena hanya tersisa bagian bawah berupa tiga lapis bata, maka bentuk atasnya sulit sekali untuk direkonstruksi.

Sekitar 75 meter di sebelah utara reruntuhan bekas candi bata tersebut terdapat kompleks makam yang dikenal dengan nama Makam Iranata. Kompleks makam tersebut selain berisi makam Pangeran Iranata sebagai tokoh utama juga terdapat makam sejumlah tokoh lain yang tidak diketahui identitasnya, dan terdapat juga lingga bagian atas yang berbentuk lingkaran berdiameter $30 \mathrm{~cm}$. Ketinggian linga tersebut sekitar $30 \mathrm{~cm}$ di atas tanah, dan masih terdapat bagian yang berada di dalam tanah. Namun demikian setelah dilakukan penggalian ternyata lingga tersebut tidak utuh lagi, karena bagian bawah sudah tidak ada. Secara keseluruhan bagian yang menancap di bawah

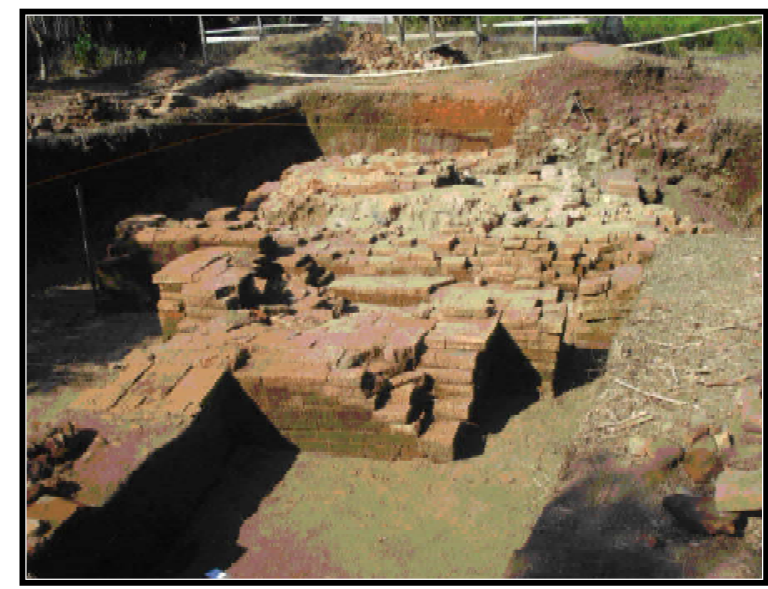

Foto 1. Reruntuhan Candi Negeri Baru dilihat dari arah barat daya (dok. Balai Arkeologi Banjarmasin).

permukaan tanah hanya $20 \mathrm{~cm}$. Sampai saat ini belum dapat disimpulkan bagaimana hubungan antara lingga dengan reruntuhan bangunan candi bata tersebut. Hal ini dikarenakan belum adanya faktor pendukung yang lain yaitu arca penyerta dan prasasti yang menginformasikan keberadaannya.

Makam Pangeran Iranata memiliki nisan yang dibuat dari batu hitam, berbentuk bulat seperti gada, dan bagian atas meruncing. Pada nisan yang berwarna warna hitam tersebut terdapat inskripsi menggunakan huruf Arab berisi nama tokoh dan tahun namun sudah 
aus. Tulisan yang masih dapat dibaca berbunyi marhum pangeran ira ..... Mungkin tokoh inilah yang dimaksudkan dalam cerita lisan masyarakat sebagai pendiri candi tersebut. Cerita lisan juga mengungkapkan bahwa Pangeran Iranata diislamkan oleh tokoh-tokoh yang dimakamkan di Keramat Tujuh dan Keramat Sembilan.

Pada waktu pembangunan cungkup di kompleks makam tersebut, pernah ditemukan sejumlah pecahan keramik yang berasal dari berbagai jenis wadah dan ada juga pecahan patung pohon hayat dari logam. Pecahan tersebut semula disimpan di cungkup makam, namun sekarang banyak yang sudah hilang tidak diketahui lagi keberadaannya. Cerita masyarakat juga menyebutkan bahwa pernah ditemukan perhiasan emas yang diperkirakan berasal dari masa lalu.

Ada suatu cerita di kalangan masyarakat yang cukup menarik mengenai keberadaan candi dan Makam Iranata. Dikatakan bahwa, di desa tersebut

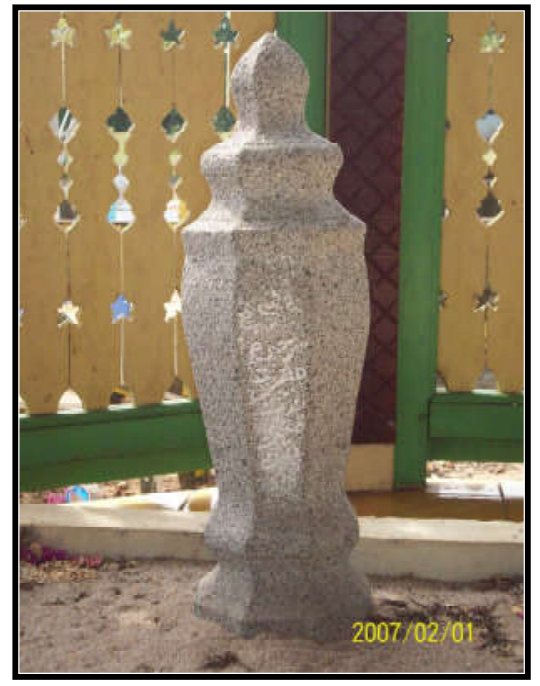

Foto 2. Nisan makam Pangern Iranata di Negeri Baru (dok. Balai Arkeologi Banjarmasin).

pada jaman Majapahit bermukim seorang penguasa yang bernama Pangeran Iranata. Beliau bermaksud mendirikan candi bata sebagai tempat persembahyangan orang Hindu. Akan tetapi sebelum bangunan tersebut selesai didirikan, datanglah serombongan orang membawa ajaran agama baru, yaitu agama Islam, dan sang pangeran tertarik untuk masuk ke agama baru tersebut. Setelah beliau masuk Islam, banyak rakyat yang ikut masuk agama baru tersebut. Akhirnya pembangunan candi dihentikan namun dibiarkan tetap utuh tidak dirobohkan, dan pada akhirnya roboh sendiri karena tidak ada lagi yang mengurusnya.
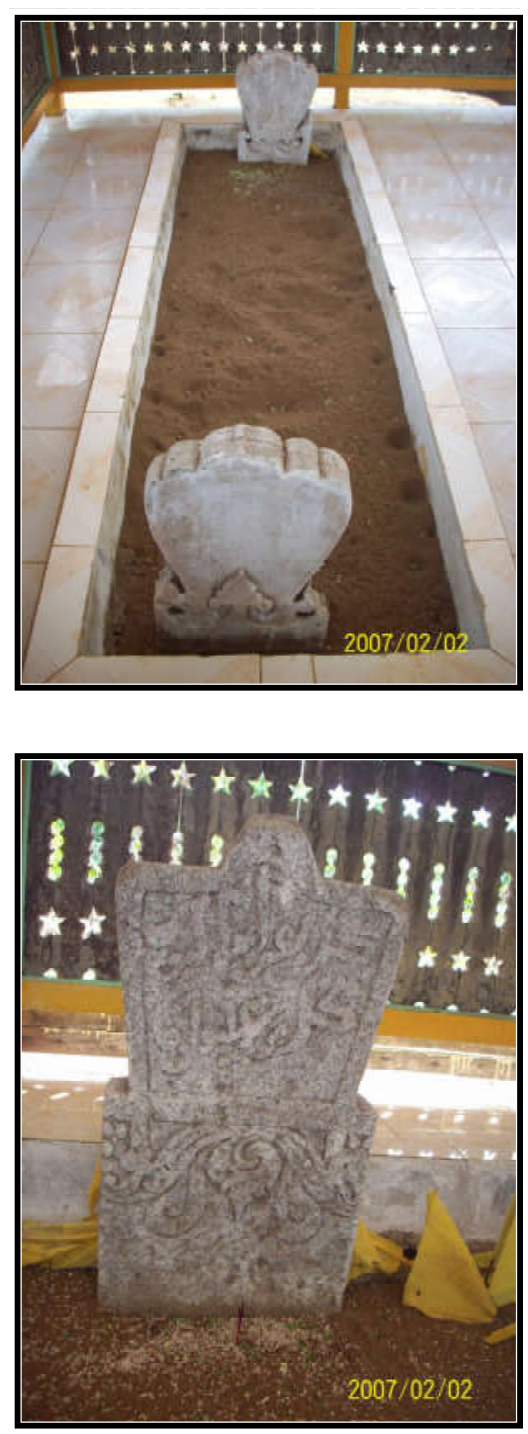

Foto 3 (atas) dan 4 (bawah). Nisam di kompleks Makam Keramat Tujuh (dok. Balai Arkeologi Banjarmasin).

Waktu terus berjalan, bakal candi tersebut tidak terurus sampai akhirnya tertutup hutan dan baru ditemukan lagi oleh masyarakat sekitar tahun 1970an. Semula masyarakat mengira bata tersebut sebagai benteng Belanda, dan mereka mengambil bata-bata yang ada sedikit demi sedikit untuk berbagai keperluan. Puncaknya terjadi pada sekitar tahun 1990-an ketika bata banyak diambil untuk dipakai sebagai bahan bangunan baru dan sebagian dijual ke luar daerah, sehingga hanya tersisa bagian-bagian yang sekarang terpendam.

Sekitar $1 \mathrm{~km}$ dari reruntuhan candi tersebut ke arah barat laut terdapat dua kompleks makam keramat, yaitu Keramat Tujuh dan Keramat Sembilan. Di kompleks makam Keramat Tujuh terdapat tujuh makam kuna bersama dengan sejumlah makam baru. Ketujuh makam kuna tersebut terbagi menjadi dua 
kelompok, kelompok pertama berisi lima makam dan kelompok kedua berisi dua makam. Masing-masing kelompok makam dinaungi dengan cungkup baru, yang menurut informasi dibangun oleh sebuah Lembaga Swadaya Masyarakat (LSM) kebudayaan. Pada kelompok pertama nisan-nisannya mempunyai hiasan sulur-suluran, inskripsi huruf Arab, bunga, serta ukiran tahun Saka 1363 dengan menggunakan huruf Jawa Kuna. Semua bentuk nisan pada kelompok pertama ini bergaya Troloyo, yaitu pipih dan bagian atas membentuk kurawal. Pada kelompok kedua yang berisi dua makam, hiasan pada makam pertama berupa hias tumpal dan sulur sederhana tanpa angka tahun. Makam kedua mempunyai hiasan garis pada bagian tengah, huruf arab yang sudah aus dan angka tahun dengan huruf jawa kuna. Pembacaan angka tidak begitu pasti apakah 1350 atau 1340 Saka. Nisan pada kedua makam tersebut juga bergaya Troloyo seperti halnya pada kelompok pertama.

Angka tahun saka dapat dengan mudah dikonversikan ke tahun masehi yaitu dengan menambahkan angka 78. Dengan demikian angka tahun saka pada inskripsi makam tujuh tersebut sama dengan tahun 1441 Masehi dan 1428 atau 1418 Masehi. Apabila diasumsikan bahwa angka tahun tersebut merupakan tahun kematian seseorang maka diperkirakan bahwa abad ke-15 M sudah terdapat sejumlah pemeluk agama Islam di Ketapang. Karena tidak adanya keterangan yang pasti, belum dapat dipastikan apakah mereka penduduk asli atau para pendatang.

Kompleks Makam Sembilan terletak sekitar 1,5 km dari kompleks Makam Tujuh. Sesuai namanya di tempat tersebut terdapat sembilan makam yang dikeramatkan. Bentuk nisan pada kompleks Makam Sembilan sama persis dengan bentuk nisan pada kompleks Makam Tujuh, yaitu memiliki langgam Troloyo. Kompleks makam tersebut juga terbagi menjadi dua kelompok, yaitu kelompok utara yang berisi dua makam dan kelompok selatan yang berisi tujuh makam. Ragam hias yang ada juga hampir sama, yaitu sulur-suluran dan inskripsi huruf Arab.

Pada kelompok yang berisi dua makam, nisan makam pertama terdapat hiasan sulur-suluran, sedangkan pada makam kedua terdapat inskripsi huruf arab pada kedua sisi nisan kepala. Kelompok yang berisi tujuh makam sebenarnya terdapat lebih dari tujuh makam kuna, namun yang dapat dikatakan masih utuh ada tujuh. Pada makam pertama bagian nisan kepala terdapat inskripsi huruf arab sedangkan pada nisan kaki terdapat angka jawa kuna 1359 Saka. Nisan pada makam kedua juga terdapat hiasan sulur tetapi tanpa angka tahun. Pada makam ketiga terdapat hiasan sulur yang dibuat melingkar serta terdapat angka 1345 Saka.
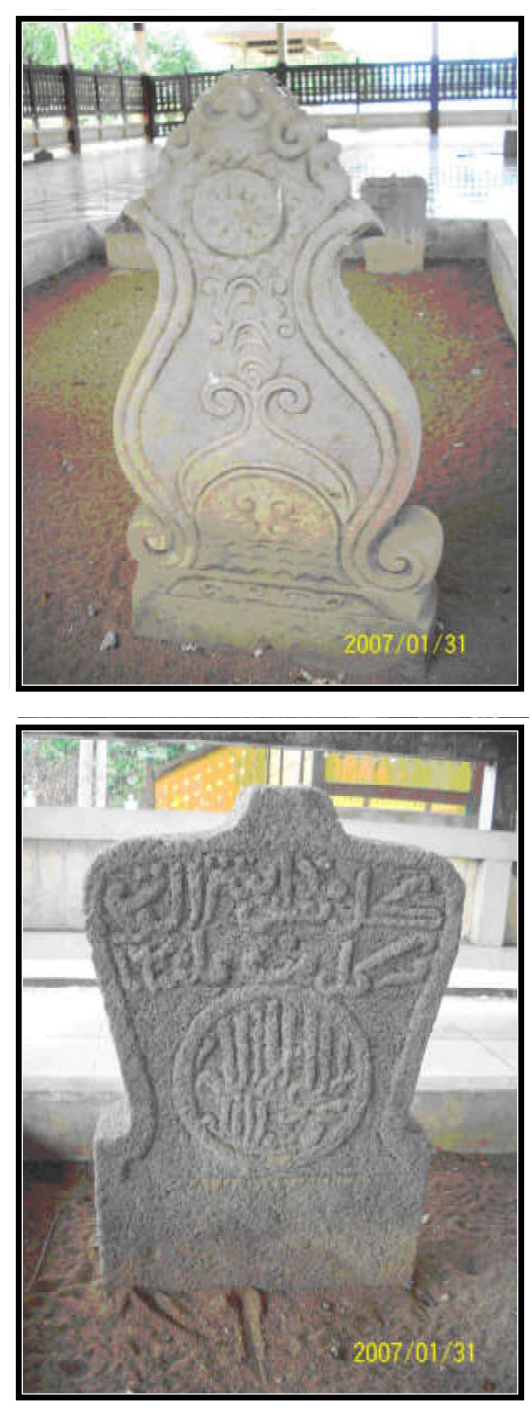

Foto 5 (atas) dan 6 (bawah). Nisam di kompleks Makam Keramat Sembilan (dok. Balai Arkeologi Banjarmasin).

Makam keempat dan kelima polos tanpa hiasan, sedangkan makam keenam dan ketujuh terdapat hiasan sulur-suluran.

Hiasan sulur-suluran merupakan sebuah ragam hias yang universal, terdapat di berbagai daerah di Indonesia, sehingga kurang memberikan informasi perkembangan seni. Beberapa makam menunjukkan pesan-pesan tertentu, yang ditunjukkan dengan adanya kaligrafi huruf Arab. Sebagai contoh terdapat tulisan yang merupakan bagian dari ayat-ayatAI Qur'an seperti surat Al Ikhlas. Surat tersebut merupakan sebuah pengakuan akan keesaaan Allah. Selain itu ada juga pesan yang dapat diterjemahkan dengan "setiap yang hidup pasti akan menjumpai kematian" dan ada juga pernyataan bahwa semua ini berasal dari Allah dan akan kembali kepada-Nya. Dengan demikian, para pembuat nisan atau yang memesan nisan untuk dipasang di tempat tersebut menggunakan nisan tersebut sebagai media dakwah. 


\section{Candi dan Makam di Negeri Baru dalam Perkembangan Budaya}

Reruntuhan bangunan bata di Desa Negeri Baru yang merupakan bagian bawah dari candi, merupakan suatu hal yang istimewa. Hal ini terkait dengan suatu pendapat umum bahwa tidak ada bangunan candi di Kalimantan Barat. Bangunan ini jelas menunjukkan bahwa sebelum Islam datang, ternyata telah berkembang suatu budaya yang dilatarbelakangi oleh agama Hindu. Di beberapa daerah lain sebenarnya juga terdapat sejumlah peninggalan yang memiliki makna yang sama, antara lain prasasti Batu Pahit di Kabupaten Sekadau dan prasasti Batu Sampei di Kabupaten Sanggau, serta adanya sisa-sisa tempat pemujaan yang berlatar belakang agama Buddha di Pulau Maya, Kabupaten Kayong Utara. Bangunan candi dari bata yang ada di Desa Negeri Baru ini jika memang benar berlatarbelakang agama Hindu atau Budha, bisa jadi mempunyai kaitan dengan peninggalan-peningalan berlatar agama Hindu dan Buddha yang lain di Kalimantan Barat. Hanya saja masih perlu penelitian lebih mendalam untuk dapat mengaitkan serpihan-serpihan sejarah tersebut di atas, sehingga dapat menjelaskan kejadian secara runtut di Kalimantan bagian barat ratusan tahun yang lalu.

Secara umum bangunan candi memiliki komponen atap, badan, dan kaki yang akhirnya menjadi tiga bagian pokok, yaitu atap candi, badan candi, dan kaki candi yang diwujudkan dengan adanya pelipitpelipit maupun profil horizontal yang mengelilingi candi. Berdasarkan bentuk denahnya, bentuk-bentuk arsitektur candi-candi pada umumnya menunjukkan kesimetrisan, kesumbuan, pemusatan, dan hierarki. Terdapat beberapa kombinasi bentuk pada beberapa candi, misalnya bentuk kaki candi bujursangkar, sedangkan badan dan atapnya berbentuk silang atau lainnya. Pada umumnya candi di Indonesia berbentuk menara dengan pembagian ruang menjadi satu ruang, empat, enam, atau bahkan tidak memiliki ruang. Yang banyak ditemukan candi beruang satu atau tunggal. Berdasarkan bahan pembuatannya, candi-candi berbentuk menara biasanya terbuat dari bahan batu, bata, atau kombinasi antara batu dan bata. Candi berbentuk menara umumnya banyak ditemukan pada candi-candi hingga masa Majapahit (PaEni, Mukhlis, Ed. 2009 (IV), 167-170).

Terkait dengan fungsi candi memang ada beberapa pendapat yang mengemuka, yang sudah berkembang sejak abad ke-19 M. Ada yang berpendapat bahwa candi merupakan tempat dimakamkannya raja yang telah meninggal, dan ada pula yang berpendapat bahwa candi merupakan tempat pemujaan. Pada dasarnya terdapat tiga pandangan yang melandasi alasan bahwa candi dianggap sebagai makam, yaitu adanya peti abu jenazah dalam perigi candi, adanya patung perwujudan atau lingga dalam bilik candi, dan adanya tempat bersemayam sang dewa di bagian puncak candi. Ketiga pandangan tersebut akhirnya bertentangan dengan pandangan Soekmono yang dikemukakan tahun 1974, yang menelaah peripih atau perigi yang sebelumnya dianggap sebagai peti batu untuk menyimpan abu jenazah. Soekmono berkesimpulan bahwa peripih merupakan tempat menyimpan benda-benda atau relik yang dianggap mewakili dan melambangkan para dewa. Akhirnya beliau berkesimpulan bahwa, candi merupakan bangunan kuil dan candi merupakan mata rantai dalam perkembangan kebudayaan Indonesia sejak jaman prasejarah sampai saat ini (Soekmono 1974, 334).

Ketika agama Islam datang, dan masyarakat sudah banyak yang memeluk agama Islam maka bangunan suci agama lama cenderung ditinggalkan dan tidak dirawat sehingga mengalami kerusakan. Kerusakan lebih diperparah lagi dengan adanya bencana alam yang melanda suatu daerah misalnya banjir dan gempa. Kedatangan dan penyebaran agama Islam yang berlangsung secara damai antara lain menyebabkan budaya pra Islam masih berkembang hingga saat ini. Masyarakat tidak dengan serta merta meninggalkan sesuatu yang sudah sejak lama digunakan untuk diganti dengan yang baru. Salah satu di antaranya adalah penggunaan huruf lama yang tidak serta merta diganti huruf arab.

Adanya penulisan huruf Jawa Kuna dan bentukbentuk nisan yang mirip dengan bentuk nisan di Troloyo menunjukkan bahwa pengaruh Jawa memang sampai di Ketapang. Pengaruh tersebut bisa saja merupakan pengaruh politik yang dapat berimbas ke pengaruh budaya, atau bisa jadi hanya pengaruh budaya saja. Apabila dilihat pada angka tahunnya maka pada saat itu yang berkuasa di Jawa adalah Kerajaan Majapahit. Di dalam kitab Negara Kertagama sendiri memang menyebutkan sejumlah nama di Kalimantan Barat yang mirip dengan nama yang ada di Ketapang dan Kayong Utara yang merupakan pecahan dari Kabupaten Ketapang. Sebagai contoh perbandingan nama Malano dengan Melano yang sekarang, Tanjung Pura (sekarang masih ada nama Desa Tanjung Pura yang memiliki peninggalan arkeologis makam-makam kerajaan), dan Kadandangan dengan Kendawangan yang merupakan sebuah pelabuhan laut.

Sebagai gambaran saja bahwa di Troloyo, sebuah kampung sebagai bagian dari Trawulan yang diyakini merupakan ibukota Majapahit, terdapat kompleks makam tujuh dan sembilan. Bentuk dan 
hiasan yang ada di makam Tralaya juga mirip dengan yang ada di Negeri Baru tersebut. Angka tahun yang ada di Troloyo berkisar dari 1198 saka sampai 1397 saka atau 1276 masehi sampai dengan 1475 masehi (EFEO 1995, 229). Dibandingkan dengan angka tahun pada makam-makam yang ada di Ketapang jelas bahwa angka-angka tahun di Tralaya tersebut lebih tua. Dengan demikian secara teoritis dapat dikatakan bahwa budaya pemakaian nisan di Negeri Baru tersebut mengadopsi pemakaian yang sama dari Trowulan, misalnya dengan memesan dari pabrik yang sama.

Melihat pada bahan yang digunakan untuk pembuatan nisan yang berupa batu hitam, menunjukkan bahwa nisan tersebut kemungkinan besar dibawa dari luar daerah. Hasil penelitian menunjukkan bahwa sekitar Negeri Baru tidak terdapat batu seperti yang untuk bahan pembuatan nisan tersebut. Bisa jadi batu nisan tersebut dibawa dalam bentuk jadi, atau mungkin juga dibawa dalam bentuk mentah dan diolah bentuknya di Ketapang. Akan tetapi, kemungkinan kedua ini relatif lebih kecil karena tentunya harus mendatangkan juga para ahli pahatnya. Mungkin juga nisan tersebut merupakan barang hadiah dari penguasa yang ada di Trowulan kepada penguasa di Ketapang. Dapat dikatakan bahwa nisan memang merupakan salah satu komoditas dagang dari masa lalu yang terus berlangsung sampai dengan saat ini. Nisan yang menggunakan bahan batu juga menunjukkan bahwa para tokoh yang dimakamkan merupakan orang terpandang, karena harga batu sebagai barang "impor" lebih mahal daripada kayu yang lebih mudah diperoleh di Ketapang.

Terlepas dari berbagai cerita dan legenda yang beredar di masyarakat, serta berdasarkan peninggalan kepurbakalaan yang ada, dapat diajukan dua asumsi. Yang pertama bahwa pada pertengahan abad ke-15 $M$, Islam sudah masuk ke Ketapang, nampaknya melalui aliran Sungai Pawan. Asumsi kedua, sebelum berkembangnya agama Islam telah terdapat peradaban Hindu yang cukup kuat terbukti dengan adanya candi di Desa Negeri Baru tersebut. Angkaangka tahun pada Makam Keramat Tujuh dan Keramat Sembilan sampai saat ini diketahui sebagai angka makam paling tua di Kalimantan Barat. Dengan kata lain penyebaran agama Islam di Ketapang terjadi lebih dahulu dibandingkan dengan daerah-daerah lain di Kalimantan Barat. Sayangnya, tidak diketahui namanama tokoh di kedua kompleks makam keramat tersebut, sehingga tidak diketahui juga asal-usul dan jenis kelamin mereka.

Agama Islam sudah masuk ke Ketapang lebih dahulu daripada beberapa daerah yang lain di
Kalimantan Barat merupakan hal yang wajar, karena Ketapang (dan Kabupaten Kayong Utara saat ini) merupakan daerah jalur perdagangan laut. Pada abad ke - $15 \mathrm{M}$, Islam sudah memiliki kedudukan yang kuat di Malaka, dan mampu melebarkan pengaruhnya ke berbagai kawasan di Indonesia (Thohir 2004, 291). Kondisi yang seperti ini memberikan akses yang cukup besar karena masyarakat pantai selalu menerima kontak dengan dunia luar lebih dahulu daripada masyarakat pedalaman. Pada saat itu Kota Pontianak belum muncul, sehingga Ketapang yang lebih dahulu muncul memiliki akses hubungan yang lebih baik. Interaksi tersebut antara lain menyebabkan masyarakat Ketapang yang juga termasuk bagian dari masyarakat Melayu mengalami percampuran dengan berbagai suku bangsa lain, misalnya Jawa, Bugis, Riau, Brunai, dan Arab. Bisa jadi pada masa tersebut para penganut agama Islam hanya merupakan bagian kecil saja, belum memiliki akses politik kepada para penguasa.

Masuknya agama Islam ke Ketapang, dalam jangka waktu tertentu mengakibatkan berbagai perubahan sosial dan budaya. Meskipun perubahan itu terasa lambat, namun tetap terdapat suatu adaptasi atau persentuhan antarbudaya sehingga memunculkan sesuatu yang baru. Sesuatu yang baru tersebut di antaranya budaya memakamkan jenazah ke dalam tanah, munculnya budaya tulis dengan menggunakan huruf Arab (minimal pada makam), dan puncaknya adalah munculnya kerajaan yang berlatar belakang agama Islam. Munculnya perubahan tersebut memang tidak serta merta, tetapi memerlukan waktu karena sebuah perubahan sosial budaya memerlukan waktu yang lama. Selain itu perubahan sebuah budaya juga dikehendaki oleh para pemilik budaya itu sendiri, baik karena pengaruh internal maupun eksternal. Biasanya pengaruh dari luar mempercepat proses perubahan tersebut (Ishomuddin 2005, 147-148).

Sebagai data pembanding, di daerah pedalaman Ketapang, yaitu di Desa Tanjung Pura, terdapat makam raja-raja Tanjungpura. Desa tersebut dapat ditempuh sekitar 2 jam dari Negeri Baru dengan menggunakan speed boat melalui Sungai Pawan ke arah pedalaman. Salah satu tokoh yang dimakamkan di tempat tersebut adalah Sultan Muhammad Jainuddin Mursal bin ibnu Iranata. Apabila tokoh tersebut memang anak Pangeran Iranata yang dimakamkan di Negeri Baru, maka kemungkinan beliau memindahkan lokasi pemerintahan lebih ke pedalaman. Menurut cerita, ladang penduduk yang ada di sekitar makam Tanjungpura tersebut dahulu merupakan kawasan istana. Meskipun demikian di tempat tersebut jarang ada temuan permukaan yang mendukung. Angka tahun yang ada pada makam Tanjung Pura rata-rata 
berasal dari abad ke-19 M, meskipun ada juga yang dari abad ke-18 M, sehingga jelas lebih muda dibandingkan dengan di Negeri Baru.

Makam tokoh-tokoh tertentu, baik makam tokoh keagamaan maupun tokoh raja-raja, pada berbagai kasus seringkali mendapatkan perlakuan lebih istimewa dibandingkan makam-makam yang lain. Keistimewaan itu antara lain terlihat dikeramatkan dan dijadikan tempat ziarah, diberi bangunan cungkup, dan nisannya lebih bagus daripada nisan makam umum. Paling tidak terdapat dua alasan mengenai perlakuan tersebut, yaitu kharisma para tokoh tersebut semasa hidupnya dan adanya tradisi pra-Islam yang masih berlanjut, yaitu pemujaan kepada arwah nenek moyang (Ambary 1998, 201). Masih adanya tradisi pra-Islam yang berlanjut juga merupakan salah satu aspek dari kedatangan Islam ke Indonesia yang tidak melalui peperangan dan kekerasan. Agama Islam datang dengan penuh rasa toleransi dan adanya rasa saling menghargai antara penduduk setempat yang memeluk agama Hindu-Buddha dengan pendatang yang beragam Islam. Pada kenyataannya nilai-nilai tradisi Hindu Buddha banyak mempengaruhi substansi maupun pelaksanaan Hukum Islam di Indonesia (Thohir 2004, 291-292).

Pada kasus Makam Keramat Tujuh, Makam Keramat Sembilan, dan makam raja-raja Tanjungpura nampaknya ada juga perlakuan khusus. Perlakuan khusus ini nampak pada dua hal yaitu diberi bangunan cungkup, dan nisannya lebih bagus daripada nisan makam umum. Perlakuan khusus terhadap makam raja-raja Tanjungpura berupa pembangunan cungkup dan penggantian nisan serta jirat pernah dilaksanakan oleh Kodam Tanjungpura yang waktu itu memiliki wilayah operasional di Kalimantan Barat. Perlakuan khusus terhadap kompleks makam tujuh dan makam sembilan berupa pembangunan cungkup. Satu hal yang agak berbeda adalah makam-makam tersebut oleh masyarakat tidak dijadikan sebagai objek ziarah utama. Meskipun makam raja-raja Tanjungpura peziarahnya agak lebih banyak dibandingkan Keramat Tujuh dan Keramat Sembilan, namun tidak seperti makam ulama atau raja-raja di tempat lain yang lebih ramai. Barangkali ini juga terkait dengan identitas yang kurang jelas dari tokoh-tokoh yang dimakamkan di makam tujuh dan makam sembilan.

Cerita yang beredar di masyarakat bahwa yang dimakamkan di Keramat Tujuh dan Keramat Sembilan merupakan tokoh pertama yang membawa agama Islam ke Ketapang. Sebagian orang menyatakan mereka setingkat dengan para wali di Jawa. Makamnya pun juga berjumlah sembilan seperti jumlah para wali di Jawa. Sebutan Wali Songo ada yang menafsirkan bukan berarti sembilan dalam arti jumlah, tetapi angka sembilan itu sebagai angka sakral. Penafsiran ini didasarkan pada kenyataan adanya para tokoh penyebar Islam lainnya, yang berada di tempattempat tertentu. Masyarakat setempat biasanya memandang kedudukan tokoh tersebut sama atau sederajat dengan tokoh wali yang sembilan orang.

Akan tetapi kebenaran cerita tersebut belum dapat dipastikan. Cerita tersebut merupakan sebuah legenda yang oleh masyarakat saling dikaitkan antara satu peristiwa dengan peristiwa lain, yang kemudian dicarikan bukti fisiknya. Legenda tentang sejarah atau suatu kejadian tertentu pada masa lalu dapat muncul dan diterima pada masa kini, antara lain karena jarak waktu yang jauh dan tidak adanya catatan tertulis yang dapat dijadikan pegangan.

Dalam khazanah pustaka, legenda adalah cerita prosa rakyat yang dianggap benar-benar terjadi tetapi tidak dianggap suci dan oleh yang empunya cerita, dan juga telah dibumbui dengan keajaiban, kesaktian, dan keistimewaan tokohnya. Tokoh-tokoh di dalam legenda digambarkan mempunyai sifat-sifat luar biasa dan sering kali juga dihubungkan dengan makhluk ajaib. Peristiwanya bersifat sekuler (keduniawian), dan sering dipandang sebagai sejarah kolektif. Legenda seringkali dipandang sebagai "sejarah". Namun, karena tidak tertulis maka kisah tersebut telah mengalami pembiasan sehingga seringkali jauh berbeda dengan kisah aslinya. Legenda yang ceritanya berkaitan dengan kehidupan keagamaan seperti tersebut di atas, dapat dikategorikan dengan legenda keagamaan. Legenda ini misalnya legenda tentang orang- orang tertentu, atau kelompok tertentu, misalnya cerita tentang para penyebar Islam di Jawa. Kelompok orang-orang ini di Jawa dikenal dengan sebutan walisongo. Mereka adalah manusia biasa, tokoh yang memang benar-benar ada, akan tetapi dalam uraian ceritanya ditampilkan sebagai figur-figur yang memiliki kesaktian, yang digambarkan di luar batas-batas kemampuan manusia biasa (Dananjaya 1991, 66-69).

Kemampuan luar biasa yang dimiliki para tokoh yang dimakamkan di Keramat Tujuh dan Keramat Sembilan adalah mereka mampu mengajak pimpinan daerah tersebut untuk masuk agama Islam. Tentunya perjuangan untuk mengajak pindah agama merupakan suatu perjuangan yang cukup berat dan tidak sembarang orang mampu melaksanakan, kecuali orang-orang yang memiliki kemampuana khusus

Sebelum kedatangan agama Islam di Ketapang tentu sudah terdapat sebuah tatanan sosial budaya yang mantap, bahkan sebuah institusi pemerintahan. Hal tersebut dibuktikan dengan adanya berbagai 
peninggalan yang mencerminkan budaya HinduBuddha, salah satu di antaranya adalah bangunan candi. Ketika Islam datang ada sebuah proses adaptasi dengan agama baru tersebut, sehingg kemudian terjadi sebuah proses perubahan budaya. Namun demikian tidak dipungkiri bahwa sebagian aspek-aspek lama tetap bertahan, karena memang ada suatu sifat konservatif yang dimiliki. Aspek tersebut memberikan suatu rasa kesuacian dan perlindungan terhadap tradisi yang dimiliki, yang sudah terbentuk dalam lambanglambang dan idiom-idiom yang disakralkan. Dengan demikian meskipun selalu ada upaya untuk melakukan perubahan, tetap saja ada bagian-bagian tertentu dari agama lama yang tetap mampu bertahan (Ishomuddin 2005, 151).

\section{Penutup}

Peninggalan kepurbakalaan bukan hanya sekedar benda mati tanpa makna, namun mempunyai berbagai makna yang dapat dipelajari oleh masyarakat. Salah satu di antaranya adalah untuk memahami berbagai perkembangan budaya yang pernah terjadi pada masa lampau pada suatu kawasan tertentu. Pemaknaan terhadap peninggalan kepurbakalaan menjadi penting, ketika masyarakat hanya memandang peninggalan sebagai barang antik yang memiliki harga mahal. Banyak sekali nilai-nilai kearifan yang muncul ketika sebuah peninggalan kepurbakalaan diteliti dan dikaji.

Pada makam-makam keramat yang ada di Negeri Baru Kabupaten Ketapang, paling tidak terdapat tiga hal yang dapat dikemukakan. Pertama adalah makam-makam keramat tersebut membuktikan bahwa kedatangan agama Islam di Ketapang terjadi lebih dahulu dibandingkan dengan wilayah lain di
Kalimantan Barat. Kedua, untuk memasukkan Islam ke dalam institusi kerajaan memerlukan waktu yang cukup lama, yang dibuktikan dengan perbandingan angka tahun pada makam-makam keramat di Negeri Baru dengan di kompleks makam Raja-raja Tanjung Pura, yaitu lebih dari seratus tahun. Ketiga, makammakam kuna tersebut mendapatkan perlakuan khusus berupa nisannya dibuat dari batu yang lebih awet dari kayu, diberi cungkup, dan dijadikan tempat ziarah mekipun bukan tempat ziarah utama. Perlakuan khusus tersebut menunjukkan bahwa penghormatan terhadap tokoh-tokoh tertentu yang sudah meninggal tetap berlangsung, meskipun tidak setinggi ketika yang bersangkutan masih hidup.

Adanya peninggalan yang bercorak Hindu seperti candi dan lingga pada tempat yang tidak berjauhan dengan kompleks makam yang merupakan peninggalan agama Islam, menunjukkan bahwa pada waktu itu kehidupan masyarakat berlangsung dengan damai dan penuh toleransi. Sampai saat ini sejumlah unsur pra Islam tetap ada di masyarakat, misalnya membakar kemenyan di makam dan melarung berbagai macam sesajian ke sungai atau hutan. Sampai dengan saat inpun kehidupan yang penuh toleransi tersebut masih tetap berlangsung damai di Ketapang.

Apabila diurutkan dari segi waktu maka peninggalan yang berupa candi lebih tua daripada makam keramat tujuh dan keramat sembilan, sedangkan makam Keramat Tujuh dan Keramat Sembilan lebih tua daripa makam raja-raja Tanjung Pura. Dengan demikian dapat dikatakan bahwa konsentrasi permukiman besar atau sebuah kota pusat pemerintahan, pernah mengalami pergeseran dari wilayah yang dekat pantai ke arah pedalaman yang berada di daerah aliran sungai.

\section{Referensi}

Ambary, Hasan Muarif. 1998. Menemukan Peradaban, Arkeologi dan Islam di Indonnesia. Jakarta: Pusat Penelitian Arkeologi Nasional.

Dananjaya, James. 1991. Folklor Indonesia, Ilmu gosip, dengeng, dan lain-lain. Jakarta: PT Pustaka Utama Grafiti. Cetakan ketiga.

EFEO. 1995. Eprigrafi dan Sejarah Nusantara. Seri terjemahan arkeologi No. 3. Jakarta: Pusat Penelitian Arkeologi Nasional.

Ishomuddin. 2005. Sosiologi Perspektif Islam. Malang: Penerbitan Universitas Muhammadiyah Malang. Cetakan pertama.
PaEni, Mukhlis. 2009. Sejarah Kebudayaan Indonesia, Arsitektur (buku IV). Jakarta: PT Raja Grafindo Perkasa.

Soekmono. 1974. Candi Fungsi dan Pengertiannya. Disertasi. Jakarta: Fakultas Sastra Universitas Indonesia.

Thohir, Ali. 2004. Perkembangan Peradaban di Kawasan Dunia Islam. Jakarta : PT Raja Garfindo Persada. 